Article

\title{
Radial Growth Rate Responses of Western Juniper (Juniperus occidentalis Hook.) to Atmospheric and Climatic Changes: A Longitudinal Study from Central Oregon, USA
}

\author{
Peter T. Soulé ${ }^{1, *}$ and Paul A. Knapp ${ }^{2}$ \\ 1 Appalachian Tree-Ring Laboratory, Department of Geography and Planning, Appalachian State University, \\ Boone, NC 28608, USA \\ 2 Carolina Tree-Ring Science Laboratory, Department of Geography, Environment, and Sustainability, \\ University of North Carolina-Greensboro, Greensboro, NC 27412, USA; paknapp@uncg.edu \\ * Correspondence: soulept@appstate.edu
}

Received: 19 September 2019; Accepted: 6 December 2019; Published: 10 December 2019

\begin{abstract}
Research Highlights: In this longitudinal study, we explore the impacts of changing atmospheric composition and increasing aridity on the radial growth rates of western juniper (WJ; Juniperus occidentalis Hook). Since we sampled from study locations with minimal human agency, we can partially control for confounding influences on radial growth (e.g., grazing and logging) and better isolate the relationships between radial growth and climatic conditions. Background and Objectives: Our primary objective is to determine if carbon dioxide $\left(\mathrm{CO}_{2}\right)$ enrichment continues to be a primary driving force for a tree species positively affected by increasing $\mathrm{CO}_{2}$ levels circa the late 1990s. Materials and Methods: We collected data from mature WJ trees on four minimally disturbed study sites in central Oregon and compared standardized radial growth rates to climatic conditions from 1905-2017 using correlation, moving-interval correlation, and regression techniques. Results: We found the primary climate driver of radial growth for WJ is antecedent moisture over a period of several months prior to and including the current growing season. Further, the moving-interval correlations revealed that these relationships are highly stable through time. Despite a trend toward increasing aridity manifested through significant increases in maximum temperatures during the summer growing season, WJ radial growth post-1960 exceeds growth pre-1960, especially during drought years. Our results support prior conclusions that increasing atmospheric $\mathrm{CO}_{2}$ increases water-use efficiency for this semiarid species, which allows the trees to continue to grow during climatic periods negatively associated with radial growth. Conclusions: Recent studies have shown that semiarid ecosystems are important for understanding global variations in carbon uptake from the atmosphere. As WJ woodlands cover an extensive region in western North America and have undergone rapid expansion during the $20^{\text {th }}$ and $21^{\text {st }}$ centuries, they may become an increasingly important carbon sink.
\end{abstract}

Keywords: western juniper; radial growth rates; carbon dioxide enrichment; aridity; summer warming; Oregon

\section{Introduction}

Western juniper (Juniperus occidentalis Hook; WJ) is a dominant tree in semiarid $(<\sim 50 \mathrm{~cm}$ annual precipitation) portions of the interior Pacific northwestern United States. The current range is roughly 3.6 million hectares [1], mostly in central Oregon east of the Cascade Mountains, but extends to portions of five western states (CA, OR, NV, WA, ID). The encroachment of WJ into ecosystems dominated by 
sagebrush (Artemesia spp.) has been examined for over 50 years [2-7]. As encroachment continues into the $21^{\text {st }}$ century [8-10], changes in the form and function of $\mathrm{WJ} /$ sagebrush ecosystems are evolving. Potential negative aspects of WJ encroachment include less soil moisture for grasses and shrubs, an increase in erosion, reduced herbaceous cover, decreased species diversity, decreased streamflow, and an increase in exposed ground [11-13]. However, some of these conclusions may not be operative [14]. The principal positive aspect of WJ encroachment relates to potential gains in carbon sequestration with a greater density of WJ trees. Globally, the largest vegetation sinks for carbon are in tropical ecosystems, but semiarid ecosystems have substantive control over the interannual variability of carbon and have become increasingly important through time [15]. Similarly, the interannual variability in global carbon uptake is directly linked to an increase in semiarid vegetation, largely in Australia [16]. Campbell et al. [10] examined the specific consequences of juniper encroachment on carbon uptake and found that the carbon sequestration component related specifically to WJ encroachment is small relative to growth. That said, WJ growth rates are steady, and the spatial potential for continued WJ expansion is large enough that continued encroachment "can have a significant impact on continental carbon stocks, even when the changes per unit area are small relative to other terrestrial carbon fluxes" due to increasing biomass ([10], p. 230).

Multiple synergistic factors have been implicated in WJ encroachment, including grazing, fire suppression, increasing seed supply, favorable climatic conditions, and carbon dioxide enrichment $[3,5-7,17,18]$. An early pulse of WJ expansion occurred in the late $19^{\text {th }}$ century and was concurrent with an extended period of favorable climate conditions [19]. Increased livestock grazing in the late 19th and early 20th century likely stimulated expansion by a combination of reducing herbaceous cover needed to sustain fires and an increase in shrub cover favorable for juvenile WJ development [19]. With 20th century fire suppression efforts the intervals between large, stand-replacing fires increased [19]. As the density and cover of WJ increased, there has been an increasing seed rain, such that more juniper promotes more juniper [7]. Through repeat vegetation sampling [20] and then using dendroecological techniques [21], the potential role of carbon dioxide enrichment in WJ encroachment was explored. The basic premise of this theory is that increasing levels of atmospheric $\mathrm{CO}_{2}$ cause increasing water-use efficiency, allowing for a potentially longer growing season and less negative impacts on WJ radial growth rates during drought periods [22-25].

In the last two decades (1998-2017), climatic conditions in central Oregon (Climate Division 7; CD7) have become warmer and drier during the western juniper growing season. Maximum temperatures in May-June were above the long-term (1905-2017) average during 70\% of the years, averaging 0.64 degrees $C$ above average during these decades. June values of the Palmer Drought Severity index (PDSI; [26]), which measures soil moisture based on precipitation and temperature conditions and is a primary determinant of radial growth for western juniper, averaged $-0.92(-1.0$ is "abnormally dry" [27]) for the 20-year period, and $45 \%$ of those years were in the "moderate drought" range ( -2.0 to -2.9$)$ or worse. In a synthesis of projected climate changes from 35 general circulation models for Oregon's Columbia River Basin, Rupp et al. [28] report that these vectors will likely continue, with increases of summer temperature of $18 \%-24 \%$ and decreases in summer precipitation of $4 \%-10 \%$ relative to the baseline period of 1979-1990. Similar vectors have been reported for the overall climate of the state of Oregon [29].

Using tree-ring data collected in the late 1990s, Knapp et al. [21] concluded that $\mathrm{CO}_{2}$ enrichment was likely a substantive driving force for WJ expansion because expansion occurred on sites where the other driving forces (e.g., livestock grazing) were absent, and was occurring in the late $20^{\text {th }}$ century during a period of unfavorable climatic conditions for WJ growth. Given that the data collected for the dendro-based investigation of the possible influence of increasing atmospheric $\mathrm{CO}_{2}$ on WJ was collected two decades ago [21], our study objective is to examine if either a $\mathrm{CO}_{2}$-fertilization effect remains operative or an acclimatization process occurred. Since we conducted our original sampling principally at federally designated Research Natural Areas, the study sites remain intact and have largely not been affected directly by anthropogenic forces such as fire suppression, logging, and grazing. 
Thus, we present a longitudinal study to assess what type of growth effect an additional 14\% (360 ppmv in 1998, 410 ppmv estimated in 2018) of atmospheric $\mathrm{CO}_{2}$ has had on these trees despite two decades of increasing aridity. We also assess if elevated $\mathrm{CO}_{2}$ can ameliorate the effects of increasing aridity on this tree species, which is a key component of a broad area of research associated with the effects atmospheric $\mathrm{CO}_{2}$ enrichment $[23,24,30,31]$.

\section{Materials and Methods}

\subsection{Field Sampling}

In September 2018, we recollected samples from live, mature WJ trees at four sites in central Oregon (Figure 1) from which we had developed tree-ring chronologies during 1996-1999 (Horse Ridge Research Natural Area, HRR; The Island Research Natural Area, IRR; Powell Butte Research Natural Area, PBR; [21]), and 2006 (Quarry Study Site, QRJ; [32]) All the sites are open canopy, minimally disturbed WJ woodlands, and three of the sites (HRR, IRR, PBR) are recognized as areas of ecological importance by their designation as Research Natural Areas [33]. At each site, we collected a minimum of two core samples from 20-30 trees using a selective sampling strategy and Haglof 5.03 mm diameter increment borers. All of the trees we sampled were in in clear open-canopy locations (i.e., no overlap of an individual tree canopy with another tree), and we avoided sampling trees where the radial growth patterns may have been compromised by lightning strikes, pathogens such as dwarf mistletoe (Arceuthobium spp.), or fires that produced significant fire scars. As with any tree-ring study based on sampling of live trees only, the potential for a non-quantifiable type of bias (i.e., "slow-grower survivorship bias") ([34], p. 6832]) exists within our sampling framework. As we had existing chronologies for each site, we combined samples from the two chronologies to create a new chronology extending through 2017. Whenever the 2018 collection site overlapped with the original collection site, we used only one core per tree in the chronology from the early sample and only one from the 2018 sample, thus assuring that no more than two core samples from any individual tree were included. Since we mixed tree-ring samples from different eras of fieldwork (c.f., [21,32]), it was necessary to exclude some samples from inclusion in the chronology. When we had to choose between including an A, B (or sometimes C) core from an individual tree, we generally retained the sample with the highest individual interseries correlation (thus, in closest agreement with the remaining samples in the chronology). However, in some cases, we retained a given sample with a lower interseries correlation if it contained a longer record. Overall, we followed a similar strategy as our prior work ([21], p. 95) in that we sought to include "the cores with the clearest ring structure (to facilitate crossdating and measurement) and longest sequences (providing greater comparative analysis)".

Our selection of western juniper is based on several criteria. First, western juniper woodlands occur within semiarid environments [35] where the effects of increasing aridity may make them among the first species to be affected by the changing environmental conditions in the Pacific Northwest. Second, the species is considered dendroclimatically important as it exhibits clear annual growth rings and strong interannual ring-width variability (relating to environmental sensitivity). Third, research has suggested that older trees are particularly sensitive to environmental change such as rising atmospheric $\mathrm{CO}_{2}$ [36-38], and our study sites are comprised of many old-growth trees exceeding 300 years of age. Finally, our prior work (e.g., [21,24,32]) has demonstrated that climate/radial growth responses can be modeled with a single variable-June PDSI. Thus, the ability to examine the effects of other factors when radial growth exceeds that predicted by climate alone is simplified. 


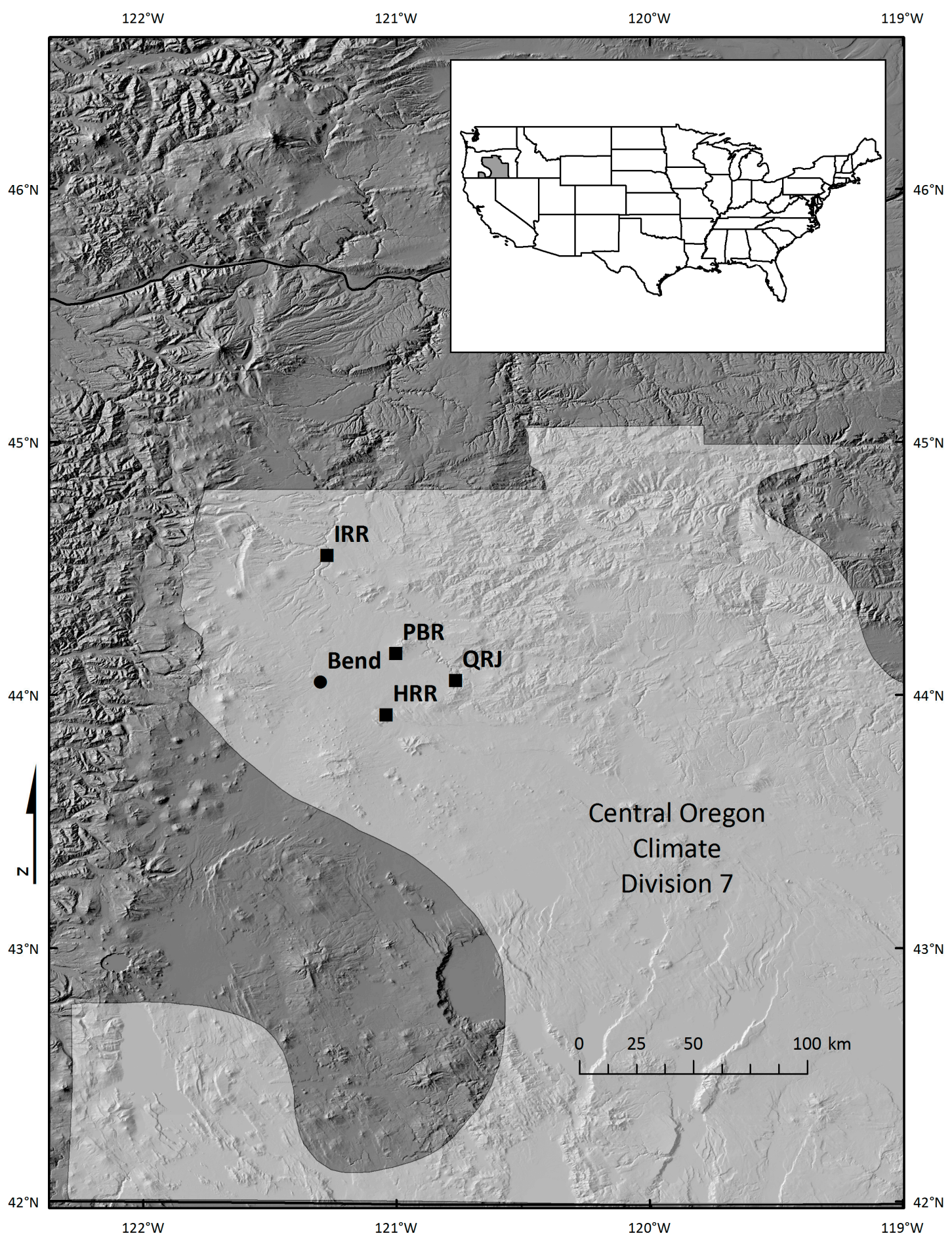

Figure 1. Locations of the four study sites and boundaries for Oregon Climatic Division 7.

\subsection{Laboratory Processing and Chronology Development}

We sanded each sample until the cellular structure was clear and then crossdated the samples using the list method [39] with the original chronology providing signature growth years (low or high) until at least the mid-1990s. We measured the samples collected in 2018 using the computer program WINDENDRO [40]. We combined the older and newer samples and checked the accuracy of our crossdating using COFECHA [41]. For dendroecological research, WJ is an excellent species to work with as it typically produces both high interseries correlation and mean sensitivity. We used the program ARSTAN [42] to standardize the new chronologies. We experimented with different standardization 
techniques and found that the negative exponential option with the standard chronology produced virtually identical annual growth values as the other techniques (e.g., cubic spline, Appendix 1). As negative exponential was the technique we had used in previous work with this species [21,24,32], our selection of negative exponential also allows for more direct comparisons between this project and prior work. In addition to the individual chronologies, we created a regional chronology (hereafter COMBO) combining all the samples from the four sites.

\subsection{Statistical Analyses}

We examined climate/growth relationships using data from Oregon Climate Division 7 (Figure 1). Specifically, we examined relationships between radial growth from the four sites plus COMBO and precipitation, minimum, average, and maximum temperature, and the PDSI using Pearson correlation. Although these data extend to 1895, Keim [43] has demonstrated that the early portion of the record is impacted by a lack of stations, so we began our analyses in 1905 and they extend through 2017, which is the last year of complete radial growth for our samples. We examined monthly relationships from October of the prior year through September of the current year. We also created and analyzed relationships from several multi-month variables (e.g., average temperature June-August). From these initial correlation analyses, we learned that the strongest climate/growth relationships existed with the regional-average chronology (COMBO), so we used COMBO exclusively for the remaining analyses.

After identifying the precipitation, temperature, and PDSI climatic variables most strongly associated with radial growth, we developed bivariate and multivariate linear regression models for COMBO. We used stepwise regression to determine which variable or combination of variables would produce a model that is logical, statistically valid, and offers a high degree of explanatory power. As PDSI is a water balance-based measure of drought severity that includes impacts of both precipitation and temperature, we could only examine it using bivariate models. We examined standardized residuals from each model for autocorrelation using Pearson correlation between the residuals and time. For growth/climate models, the presence of temporal autocorrelation has been used as an indicator in which some additional exogenous factor (e.g., $\mathrm{CO}_{2}$ ) is affecting radial growth $[21,44,45]$. As one of the objectives of this study is to address the potential for a continuing influence of atmospheric $\mathrm{CO}_{2}$ enrichment on radial growth, we added $\mathrm{CO}_{2}$ as an additional predictive variable when autocorrelation was detected with $p<0.10$.

We tested for long-term (1905-2017) and shorter-term (last 50, 30, and 20-year) linear trends in the single month and multi-month precipitation, temperature, and PDSI variables most closely associated with standardized radial growth from the COMBO chronology using Pearson correlation. For the precipitation, temperature, and PDSI variables included in regression models (excluding $\mathrm{CO}_{2}$ ), we examined the temporal stability of the growth/climate relationships using a 24-year moving interval analysis procedure and the program Dendoclim2002 [46].

As PDSI incorporates both the supply and demand for moisture and has been shown to be a driving force for WJ growth in this region [32], we used the PDSI variable most strongly related to COMBO (June PDSI) to identify possible changes in radial growth associated with changing climatic conditions in the region or $\mathrm{CO}_{2}$ enrichment. We first split the data into equal-length early (1905-1960, mean $\mathrm{CO}_{2} 306.9$ ppmv) and late (1962-2017, mean $\mathrm{CO}_{2} 353.5$ ppmv) periods. Then, we compared rates of COMBO standardized radial growth using several categories of drought (moisture) severity (e.g., all years early versus late when PDSI $<-3.0)$. We tested for significant $(p<0.05)$ difference in radial growth and PDSI values between early and late periods using a Mann-Whitney U test. We also calculated mean radial growth for COMBO and June PDSI values by pentad and present the temporal patterns.

\section{Results}

All four tree-ring chronologies had high interseries correlations and mean sensitivity, and there is a high degree of covariance among the four sites (Table 1). At the four study sites and for COMBO, the climatic variable most closely related to standardized radial growth is the total precipitation from 
October of the prior year through June of the current year (Table 2). For PDSI, in all cases, we found June to be positively and significantly $(p<0.01)$ associated with standardized radial growth (Table 2). Although the magnitude of these relationships is less than for prior October-June precipitation, in all cases, there was no significant difference $(p>0.05)$ in the two $r$ values based on a Fisher r-to-z transformation test. For temperature, we found that the average maximum temperature of May and June was negatively related to radial growth at three of the study sites, and for COMBO, and maximum June-August temperature was the strongest at IRR (Table 2). While the temperature relationships are much weaker than either precipitation or PDSI, they are moderately strong and significant $(p<0.05)$ and demonstrate that thermal conditions in late spring to early summer play an important role in modulating western juniper radial growth.

Table 1. Study sites chronology information and Pearson $r$-values between chronologies using standardized radial growth from 1905-2017 (* = significant at $p<0.01)$.

\begin{tabular}{|c|c|c|c|c|c|c|c|c|}
\hline \multirow{2}{*}{$\begin{array}{c}\text { Study } \\
\text { Site }\end{array}$} & \multirow[t]{2}{*}{ \#Samples } & \multirow{2}{*}{$\begin{array}{l}\text { Interseries } \\
\text { Correlation }\end{array}$} & \multirow{2}{*}{$\begin{array}{c}\text { Mean } \\
\text { Sensitivity }\end{array}$} & \multirow{2}{*}{$\begin{array}{l}\text { Mean Length of } \\
\text { Chronology (years) }\end{array}$} & \multicolumn{4}{|c|}{$\begin{array}{c}r \text {-Value between Sites } \\
(1905-2017)\end{array}$} \\
\hline & & & & & HRR & IRR & QRJ & PBR \\
\hline HRR & 33 & 0.87 & 0.59 & 178.9 & - & $0.75 *$ & $0.8 *$ & $0.76^{*}$ \\
\hline IRR & 32 & 0.85 & 0.6 & 140.9 & & - & $0.68 *$ & 0.71 * \\
\hline QRJ & 30 & 0.86 & 0.66 & 147.2 & & & - & $0.8^{*}$ \\
\hline PBR & 30 & 0.8 & 0.72 & 169.2 & & & & - \\
\hline COMBO & 125 & 0.78 & 0.64 & 159.2 & & & & \\
\hline
\end{tabular}

Table 2. Strongest relationships between standardized radial growth and precipitation, temperature, and Palmer Drought Severity index (PDSI) variables for individual sites and COMBO (* indicates significant relationship at $p<0.01)$.

\begin{tabular}{ccc}
\hline Site & Precipitation Variable & Pearson $r$-Value \\
\hline QRJ & prior October to June & $0.74^{*}$ \\
HRR & prior October to June & $0.68^{*}$ \\
PBR & prior October to June & $0.71^{*}$ \\
IRR & prior October to June & $0.67^{*}$ \\
COMBO & prior October to June & $0.78^{*}$ \\
\hline Site & Temperature Variable & Pearson $r$-Value \\
QRJ & May-June maximum & $-0.41^{*}$ \\
HRR & May-June maximum & $-0.35^{*}$ \\
PBR & May-June maximum & $-0.36^{*}$ \\
IRR & June-August maximum & $-0.32^{*}$ \\
COMBO & May-June maximum & $-0.4^{*}$ \\
\hline Site & PDSI Variable & Pearson $r$-Value \\
QRJ & June & $0.71^{*}$ \\
HRR & June & $0.64^{*}$ \\
PBR & June & $0.67^{*}$ \\
IRR & June & $0.66^{*}$ \\
COMBO & June & $0.74^{*}$ \\
\hline
\end{tabular}

The temporal pattern of climate/growth relationships from October of the prior year to September of the current year further illustrates the interplay of precipitation and moisture on the radial growth of western juniper in the region (Figure 2). For precipitation, there is no singular month that provides anywhere close to the strength of the total precipitation between the prior October and June, with both early winter (i.e., prior December and January) and late spring to early summer (i.e., May) of approximately equal importance. The influence of temperature is not significant until spring, and peaks in June. The combination of a positive influence of moisture supply and negative influence of moisture demand on western juniper radial growth rates is succinctly illustrated by the monthly 
temporal pattern of the water balance-based PDSI, with a steady increase in $r$-values from October of the prior year, which peak in importance in June of the current growing season.

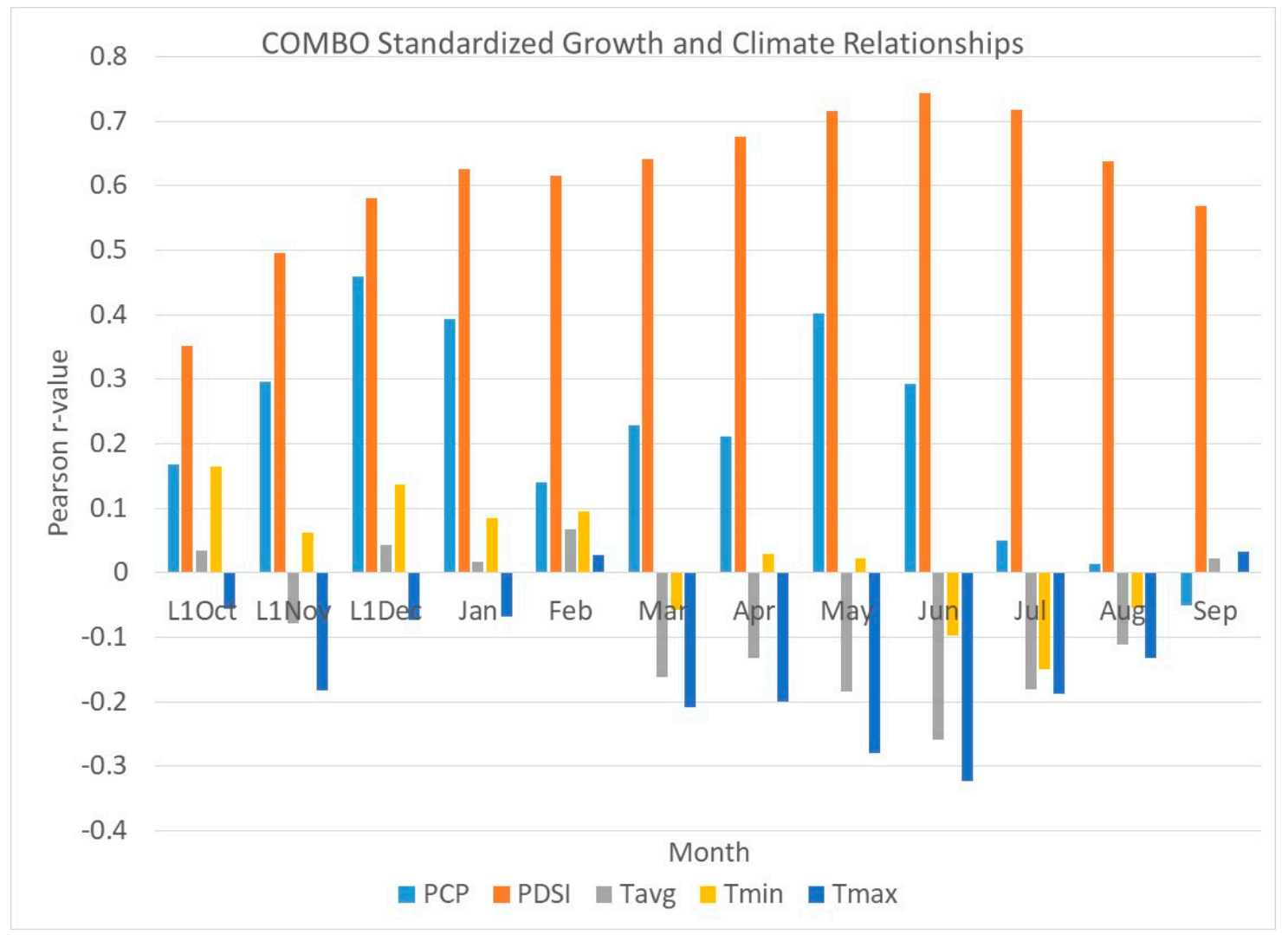

Figure 2. Pearson correlation relationships between COMBO standardized radial growth and monthly climatic conditions from October of the prior year (L1Oct) through September of the current year, 1905-2017. Variables examined included monthly total precipitation, Palmer Drought Severity index (PDSI), and minimum, maximum, and mean air temperature. All climate data from Oregon Climatic Division 7. Statistical significance $(p<0.05)$ begins at approximately $+/--0.20$.

The strongest bivariate growth climate model explains $60.1 \%$ of the variance in COMBO radial growth using prior October to June precipitation as the explanatory variable (Table 3). Residuals from this model were not temporally autocorrelated. The combined effects of precipitation and temperature are illustrated by a multivariate regression model including both prior October-June precipitation and May-June maximum temperature, which explains $62.5 \%$ of the variance in standardized radial growth. Much of the explanatory power for this model is supplied by the positive influence of precipitation, with an $R^{2}$ change of $2.4 \%$ associated with the addition of the maximum May-June temperature, which negatively affects growth. Residuals from this model were weakly autocorrelated with time $(p<0.01)$. The bivariate model that we created using June PDSI is able to explain $55.4 \%$ of the variance in standardized radial growth (Table 3). Residuals from this model were strongly autocorrelated with time $(p<0.01)$. When we added $\mathrm{CO}_{2}$ as an additional explanatory variable to the June PDSI model, we obtained a statistically valid model with explanatory power of $57.8 \%$, an $R^{2}$ change of $2.4 \%$, and the residuals were not temporally autocorrelated $(p>0.05)$. 
Table 3. Regression model statistics where standardized radial growth is the dependent variable and the explanatory variables are climatic parameters based on 1905-2017 observations. COMBO is the multi-site measurement of radial growth; O_Jppt is total precipitation $(\mathrm{cm})$ from the prior year October through the current year June; MJTmax is the average of the May-June maximum temperature $\left({ }^{\circ} \mathrm{C}\right)$; JunePDSI is the value of the Palmer Drought Severity Index in June; $\mathrm{CO}_{2}$ is the annual atmospheric carbon dioxide level (ppmv). Climate variables are from Oregon Climate Division Seven; $\mathrm{CO}_{2}$ data are from Mauna Loa observations (1958-2017) and ice cores (1905-1957) from the Scripps $\mathrm{CO}_{2}$ Program (http://scrippsco2.ucsd.edu).

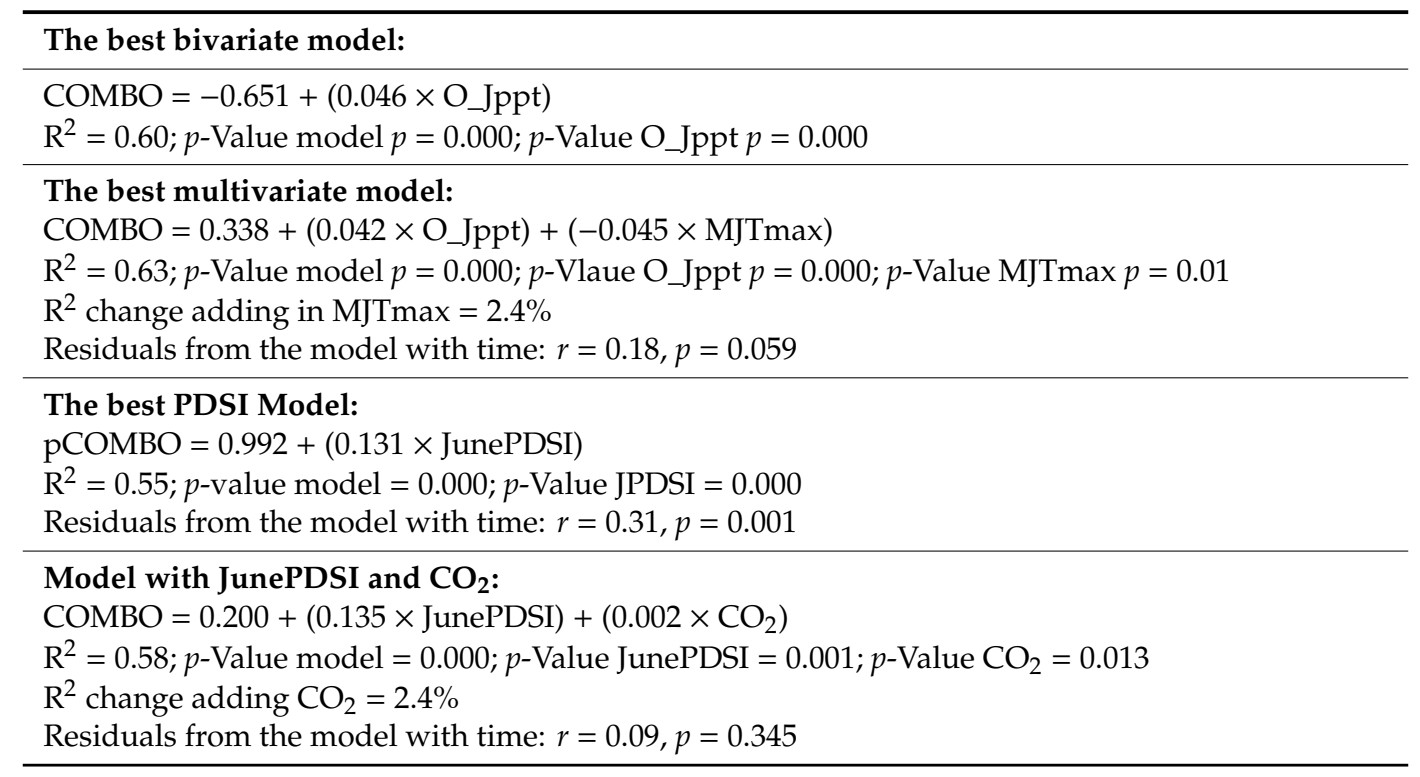

There are no significant trends in COMBO radial growth for any of the four time periods examined (Table 4). While COMBO has a positive slope over the full data period (Figure 3), in the last 50, 30 and 20 years, this has switched to a negative slope (Table 4). Long-term (1905-2017) temporal trends for the variables included in the regression models reveal the potential importance of changing climatic conditions on western juniper radial growth (Figure 3). While only the maximum May-June temperature has a significant $(p<0.05)$ long-term trend among the climate variables (Table 4$)$ included in the regression models, it is clearly a driving force for PDSI values that have a weakly negative long-term slope despite a weakly positive upward slope compared to prior October-June precipitation. Long-term trends in $\mathrm{CO}_{2}$ are strongly upward in a non-linear fashion (Figure 3d). Among the individual monthly variables most strongly related to standardized radial growth (Figure 2), only the June maximum temperature had a significant long-term trend (Table 4). We also examined shorter-term climate changes (i.e., the last 20 years) and found no significant trends, although most variables were trending in the same direction as the long-term (i.e., positive or negative; Table 4). While the primary drivers of radial growth from prior October-June precipitation and/or June PDSI have essentially a flat trend line over the last three and two decades, the May-June temperatures continue to exhibit a positive slope.

For both prior October-June precipitation and June PDSI, the climate/growth relationships are stable through time, with every 24-year window producing significant $(p<0.05)$, positive, and strong correlation values (mean moving interval correlation of 0.8 for prior October-June precipitation and 0.79 for June PSDI (Figure 4). For the May-June maximum temperature, we found significant $(p<0.05)$ negative relationships for every 24-year window through 1963 and after 2001, but several windows with non-significant relationships in the middle decades of the record. 
Table 4. Temporal trends (via Pearson $r$-Values) of the COMBO chronology and the climate variables most closely associated with standardized radial growth from the COMBO chronology. $\left({ }^{*}=\right.$ significant at $p<0.01)$.

\begin{tabular}{lcccc}
\hline & Full Record & Last 50 Years & Last 30 Years & Last 20 Years \\
\cline { 2 - 5 } & $\mathbf{( 1 9 0 5 - 2 0 1 7 )}$ & $\mathbf{( 1 9 6 8 - 2 0 1 7 )}$ & $\mathbf{( 1 9 8 8 - 2 0 1 7 )}$ & $\mathbf{( 1 9 9 8 - 2 0 1 7 )}$ \\
\hline Variable (COMBO) & 0.13 & -0.00 & -0.01 & -0.09 \\
Variable (Single Month) & & & & 0.27 \\
Prior December Precipitation & 0.16 & 0.11 & -0.03 & -0.06 \\
June PDSI & -0.1 & -0.09 & 0.24 & 0.17 \\
June Maximum Temperature & $0.24^{*}$ & 0.12 & & 0.03 \\
Variable (Multi-Month) & & & -0.01 & 0.23 \\
Prior October-June Precipitation & 0.09 & -0.02 & 0.2 & \\
May-June Average Max Temp & $0.26^{*}$ & 0.12 & & \\
\hline
\end{tabular}

The comparison of pentadal mean values of COMBO radial growth and June PDSI reveals a generally expected pattern, with growth values above normal (i.e., $>1$ ) during wet years (+PDSI) and below normal (i.e., $<1$ ) in dry years (-PDSI) through the middle portion of the record (i.e., 1960; Figure 5). However, post-1965, there are four pentads (1965, 1985, 2005, and 2015) that record above normal growth in conjunction with negative PDSI values. In comparing the mean values of COMBO early (1905-1960) versus late (1962-2017), growth was consistently greater in the late period (Table 5). We found the greatest absolute differences during years with extreme drought (PDSI $<-3$ ). While this was not statistically significant $(p>0.05)$, the number of years with PDSI $<-3$ produced a small sample size. For PDSI years $<-2$, the growth in the later years was significantly different from the early period $(p<0.05)$.

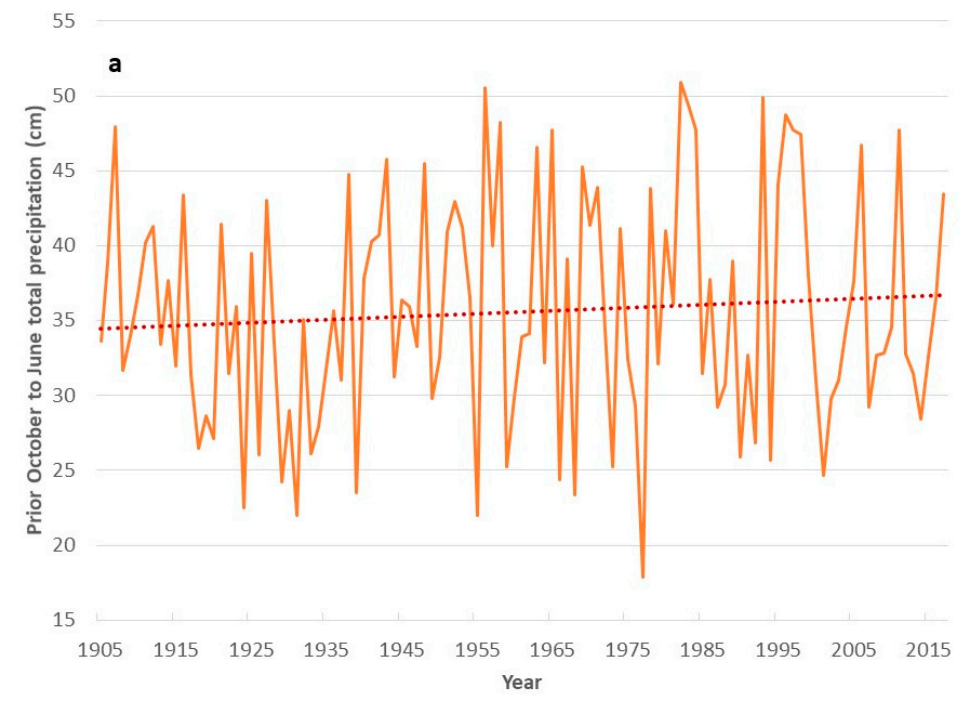

Figure 3. Cont. 

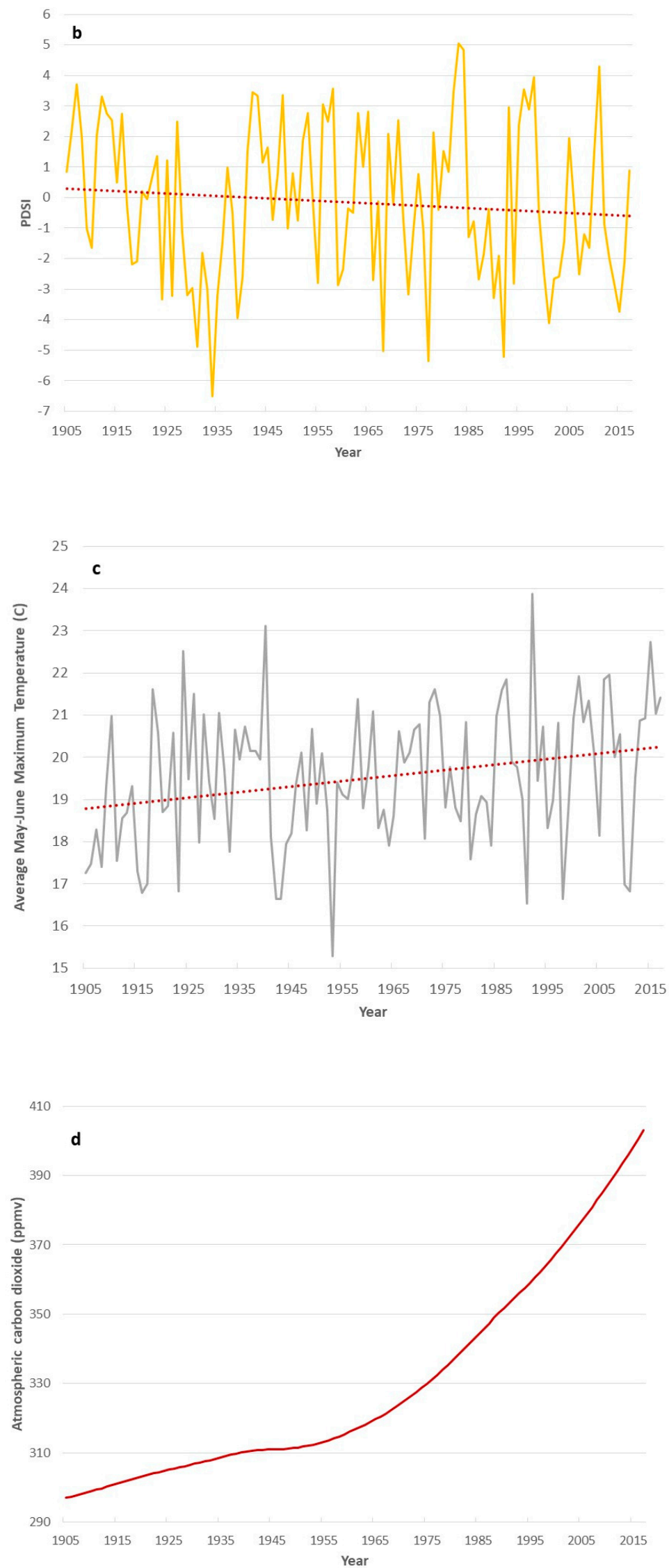

Figure 3. Cont. 


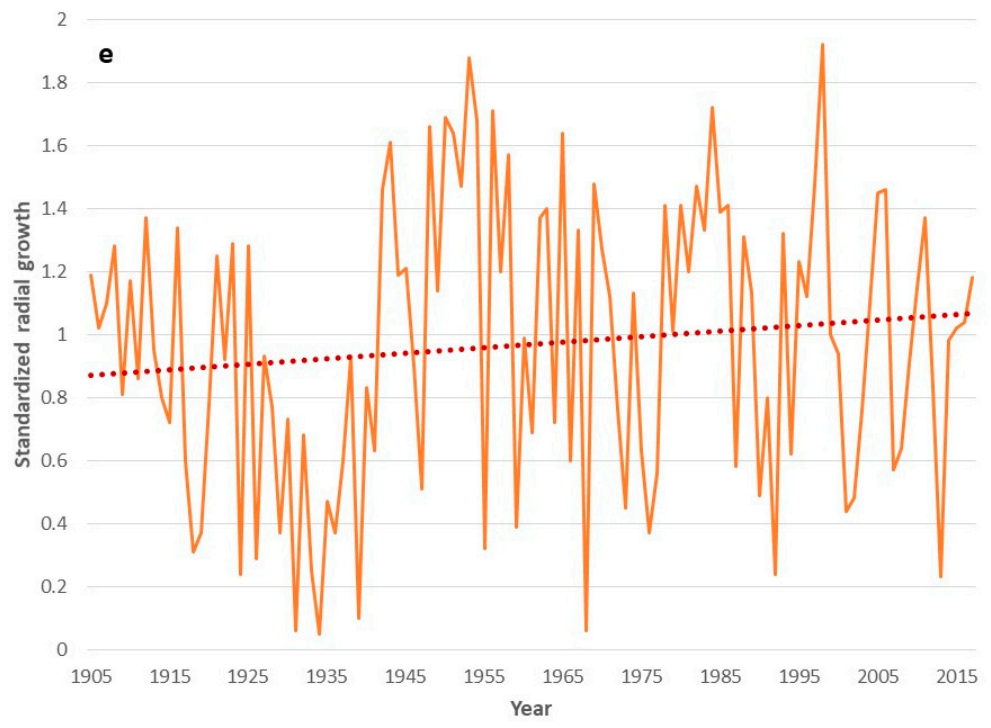

Figure 3. Temporal patterns (1905-2017) for (a) prior-year October-June total precipitation (cm), (b) June PDSI, (c) average maximum temperature $\left({ }^{\circ} \mathrm{C}\right)$ for May-June, (d) annual atmospheric $\mathrm{CO}_{2}$ concentrations (ppmv), and (e) standardized radial growth for COMBO.

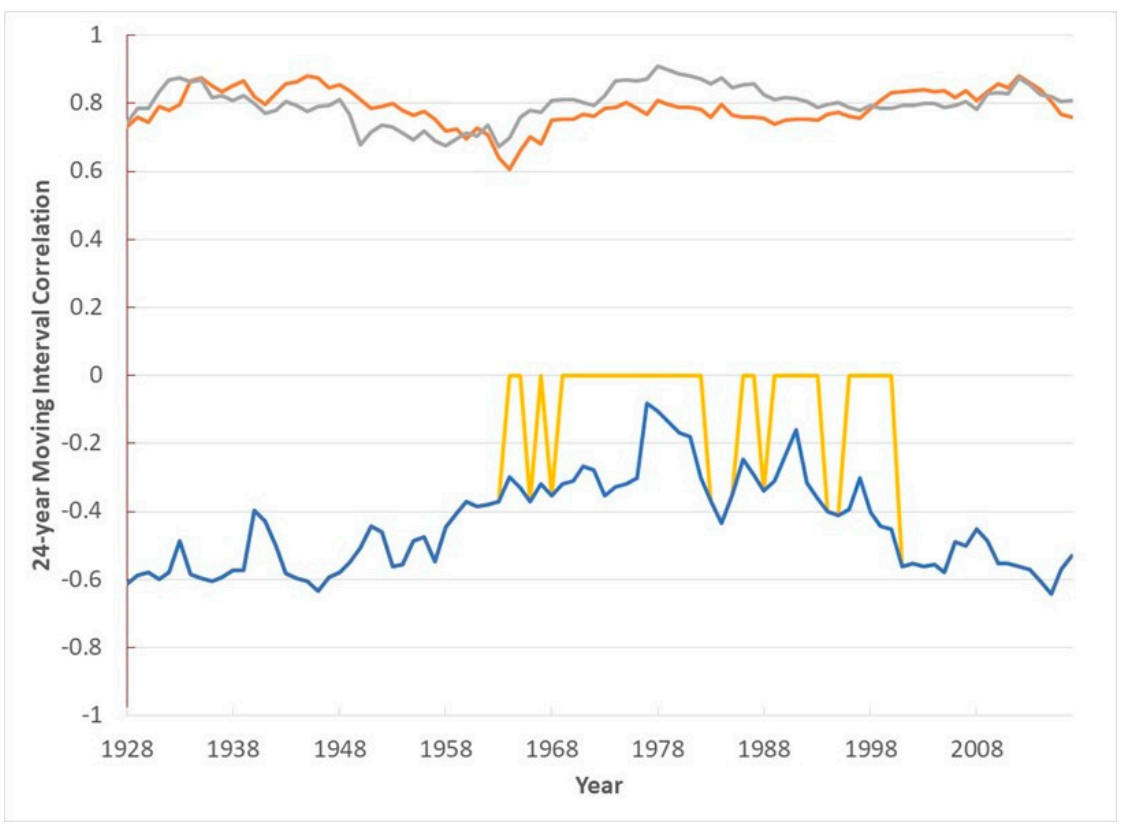

Figure 4. Significant $(p<0.05)$ 24-year moving interval correlation values between COMBO standardized radial growth and prior October-June precipitation (gray line) and June PDSI (orange line). All correlations between $\mathrm{COMBO}$ and May-June maximum temperature are shown with a blue line, 24-year windows when those correlations are non-significant $(p>0.05)$ are shown with a gold line. 


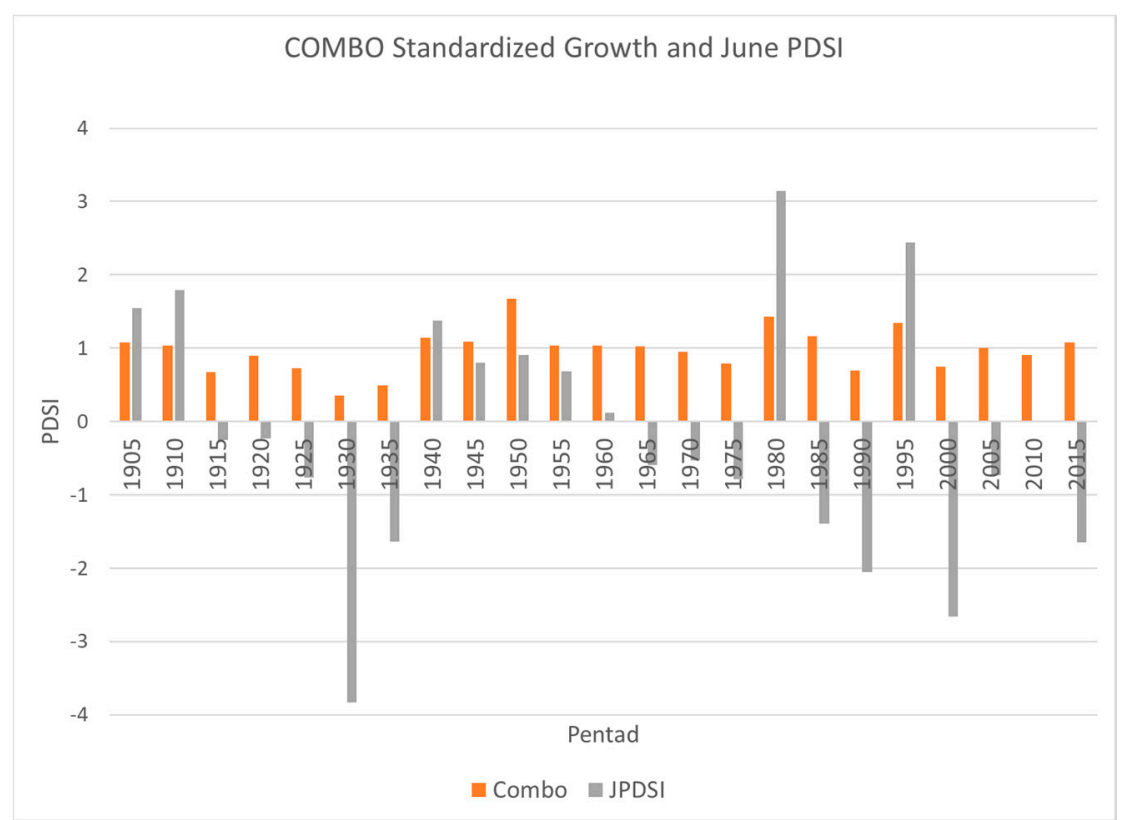

Figure 5. Pentadal values of standardized radial growth for COMBO and June PDSI at Oregon Climatic Division 7. 1905 pentad is 1905-1909, and the final pentad is only three years, 2015-2017.

Table 5. Comparison of COMBO standardized radial growth early (1905-1960) and (late 1962-2017) by June PDSI category ( $p$-Values are from a Mann-Whitney $U$ test, with significant $(p<0.05)$ differences boldfaced).

\begin{tabular}{cccc}
\hline & PDSI $<-3$ & & \\
\hline & PDSI & Growth & \# years \\
EARLY & -3.9 & 0.23 & 8 \\
LATE & -4.3 & 0.47 & 7 \\
$p$-Value & 0.315 & 0.132 & \\
& PDSI $<-2$ & & \# years \\
& PDSI & Growth & 15 \\
EARLY & -3.3 & 0.38 & 17 \\
LATE & -3.3 & 0.59 & \\
$p$-Value & 0.479 & $\mathbf{0 . 0 3 4}$ & 21 \\
& PDSI $<-\mathbf{1}$ & & 25 \\
EARLY & PDSI & Growth & \\
LATE & -2.7 & 0.51 & 0.71 \\
$p$-Value & -2.7 & 0.236 & \\
\hline
\end{tabular}

\section{Discussion}

One of the benefits of working in minimally disturbed western juniper woodlands is that radial growth responses to changing climatic conditions or increasing $\mathrm{CO}_{2}$ should not be masked by other exogenous factors. Events such as grazing, logging, and road building, either operating individually or together, can alter the surrounding environment of trees by affecting the amounts of light, nutrients, and soil-water availability [47]. By sampling on established Research Natural Areas, the potential effects of human activities on radial growth are minimized. Further, each site represents an open-canopy woodland; thus, the trees are not subject to changes in light intensity caused by infilling. While some western juniper trees are host to dwarf mistletoe (Phoradendron juniperinum), which could potentially reduce radial growth rates, we did not sample trees with colonies of the parasite plant. 
The relationships between prior-year October-June cumulative precipitation and radial growth were all significant $(p<0.01)$ and positive, reflecting the importance of cumulative water supply over several months prior to the peak summer growing season. This result was expected, as Knapp et al. [21] found October-June precipitation to be the variable most strongly associated with the radial growth of western juniper based on chronologies developed within the region in the 1990s and including three of our study sites (HRR, PBR, and IRR). In southern Oregon, Knutson and Pyke [48] also found October-June precipitation to be the most important driver of radial growth at the majority of 17 western juniper study locations. The other climate variable that is strongly related to WJ radial growth is June PDSI. That these two measures are providing similar explanatory power for western juniper radial growth is expected, as the calculation procedures for the PDSI incorporate antecedent moisture conditions over multiple months [26]. Knapp and Soulé [32] also found June PDSI values to be strongly related to WJ radial growth at 11 sites in central Oregon. As we also found significant and negative relationships between radial growth and May-June maximum temperature, years with ample water supplied through precipitation combined with low rates of evapotranspiration will be conducive for radial growth. Conversely, drought years in this region are typically associated with persistent upper-level ridging that both reduces precipitation and leads to above normal temperatures, leading to moisture deficits and low rates of radial growth.

Testing residuals from regression models for temporal autocorrelation is a metric that has been used in prior research to suggest that an important exogenous factor for radial growth (such as $\left.\mathrm{CO}_{2}\right)$ was not reflected in the model (e.g., [21,44]). For our June PDSI model and our multivariate model with prior October-June precipitation and May-June maximum temperature, the residuals were positively autocorrelated, suggesting that radial growth in the later portion of the record was overpredicted. In exploring the potential impacts of carbon dioxide enrichment on the radial growth of western juniper, Knapp and Soulé [32] showed that $\mathrm{CO}_{2}$ could be successfully used as a predictor in multiple regression models. Adding $\mathrm{CO}_{2}$ to both these models produced a small increase in explanatory power $(2.4 \%$ for both models), which is substantively less than the $14 \%$ for WJ trees in the same region but using datasets that ended in 2006 [32]. These findings suggest that while elevated atmospheric $\mathrm{CO}_{2}$ can ameliorate the effects of increasing aridity, there may be environmental limits (e.g., prolonged drought) in which these benefits become inoperative (e.g., [49]).

We found that the thermal climate during the WJ growing season has become significantly warmer long-term (1905-2017), with a similar magnitude of change (although non-significant) during the last 20 years (Table 4, Figure 3). Conversely, the primary moisture variable impacting WJ growth is positively sloping for all time periods examined, with the strongest trends also occurring during the last 20 years. The impact of the temperature increases is best illustrated by June PDSI, which remains negatively sloping through time despite the increases in moisture. Although temperature is a weaker driving force for WJ radial growth than moisture, the relationship between growth and temperature is consistently negative (Table 2); thus, this aspect of climate change should be impacting WJ radial growth in an increasingly negative fashion. Although the thermal climate of the region has clearly changed, the climate/growth relationships for temperature, precipitation, and PDSI have remained largely stable. For temperature, the moving-interval correlations ranged between approximately -0.3 and -0.6 for all periods (Figure 4), which is a similar range of relationships found for both precipitation and PDSI (i.e., ranging from approximately 0.6 to 0.9 ). Perhaps the return to significant relationships between temperature and WJ growth from 1976 onwards (i.e., 24-year moving windows ending in 2000) is related to increasing temperatures.

In addressing the question if carbon dioxide enrichment continues to be an important driver for the radial growth of WJ, the most compelling evidence comes from our comparisons between radial growth and June PDSI. As previously shown (Table 2), June PDSI is a significant predictor for WJ radial growth. However, in the post-1950s era when atmospheric $\mathrm{CO}_{2}$ levels have rapidly escalated, several pentads recorded above normal radial growth despite having negative mean PDSI levels, which is an incongruent finding absent some other explanatory causal mechanism. Given that pentadal 
means could be skewed by individual years that were extremely atypical, we approached the June PDSI-based analyses a second way and found similar results (Table 5). For all three drought categories (i.e., PDSI $<-1,-2$, and -3 ), the early period (1905-1960) mean moisture conditions measured by June PDSI were either the same as the late (1962-2017) period or slightly wetter. Yet, in all three categories, the average radial growth post-1962 was greater, and significantly greater in the 17 years falling into the PDSI $<-2$ category (moderate drought). Since the observed changes in climate have not been conducive for enhanced radial growth, a logical conclusion is that some other mechanism is allowing the trees to grow better during drought conditions in the later portion of the record. We posit that in central Oregon, the most logical mechanism is that $\mathrm{CO}_{2}$ enrichment continues to increase the intrinsic water-use efficiency (iWUE; [50]) of WJ, allowing the trees to grow at relatively faster rates during periods of drought in recent decades when compared to growth experienced during drought periods of the early 20th century. Various studies have linked $\mathrm{CO}_{2}$ enrichment to increasing radial growth for trees (e.g., [21,30,42,51-55], with increasing rates of iWUE concurrent with atmospheric $\mathrm{CO}_{2}$ increases [25] continuing to be proffered as a key mechanism in recent work (e.g., [56-58]). However, in a meta-study based on global records from the International Tree Ring Databank, Gedalof and Berg [59] concluded that $\mathrm{CO}_{2}$ enrichment was the likely primary driving force for the increased radial growth of trees only $20 \%$ of the time, and that changes in photosynthesis related to increasing $\mathrm{CO}_{2}$ were more important than increases in iWUE for growth enhancement. Others have reached similar conclusions, principally that, despite increasing iWUE related to increasing levels of atmospheric $\mathrm{CO}_{2}$, there have not been commensurate increases in the growth rates of trees (e.g., [49,60,61]). Further, the synergistic reactions of trees to macroenvironmental changes such as warming, increasing aridity, and increasing $\mathrm{CO}_{2}$ levels (e.g., [38,62,63]) make it difficult to isolate the individual effects of any single driving force on radial growth.

\section{Conclusions}

This study provided us with an opportunity to conduct a longitudinal study of the driving forces behind WJ radial growth rates in central Oregon. We conclude that in the $\sim 20$ years from our initial work on this topic [21], little has changed in terms of the basic climate/growth relationships. Variables that we identified as the primary drivers of radial growth based on tree-ring and climate data ending circa 1998 remain unchanged through 2017. Further, our moving-interval analyses suggest that the climate/growth relationships have remained stable since the early portion of the $20^{\text {th }}$ century. Two of the factors we identify as being drivers of radial growth, temperature and atmospheric carbon dioxide, have experienced significant temporal changes, but one impacts growth negatively (temperature), and the other impacts growth positively. While increasing summer temperatures are making the climate in central Oregon more arid during the growing season for WJ, our results suggest that the trees are not responding in a commensurate fashion. That is, we found that several pentads since the 1960s recorded normal- to slightly above-normal radial growth rates while experiencing drought conditions, and that WJ are growing at faster rates during drought periods post-1960 relative to pre-1960. Thus, in answering the question of whether $\mathrm{CO}_{2}$ enrichment remains operative, we find evidence that suggests that the answer is yes. With increasing aridity and absent some other logical explanation, it is likely that an increasingly rich $\mathrm{CO}_{2}$ environment is allowing the trees to outperform growth expectations based on climatic conditions. Given the recent findings that semiarid environments are critical determinants of short-term variance in global carbon storage $[6,15,16]$, and the continued expansion of WJ woodlands into sagebrush-dominated ecosystems [8-10], any continued enhancement of WJ radial growth by $\mathrm{CO}_{2}$ enrichment should result in increased carbon uptake for a species that is dominant across 3.6 million hectares of the American West.

Author Contributions: Conceptualization P.T.S. and P.A.K.; methodology, P.T.S. and P.A.K.; formal analysis, P.T.S. and P.A.K.; investigation, P.T.S. and P.A.K.; writing-original draft preparation, P.T.S.; writing-review and editing, P.T.S. and P.A.K.; visualization, P.T.S. and P.A.K.; supervision, P.T.S. and P.A.K.; project administration, P.T.S. 
Funding: This research received no external funding.

Acknowledgments: Internal funding was provided by a University Research Council grant from Appalachian State University, and by a Proposal Preparation Program grant from the University of North Carolina-Greensboro. For fieldwork assistance we thank Tyler Mitchell, Stu Garrett, and Keith Hadley. For laboratory processing of collected samples we thank Tyler Mitchell, April Kaiser, Brianna Hibner, and Julia Adams.

Conflicts of Interest: The authors declare no conflict of interest.

\section{References}

1. The Gymnosperm Database. Available online: https://www.conifers.org/cu/Juniperus_occidentalis.php (accessed on 9 March 2019).

2. Burkhardt, J.W.; Tisdale, E.W. Nature and successional status of western juniper vegetation in Idaho. J. Range Manag. 1969, 1, 264-270. [CrossRef]

3. Burkhardt, J.W.; Tisdale, E.W. Causes of juniper invasion in southwestern Idaho. Ecology 1976, 57, $472-484$. [CrossRef]

4. Caraher, D.L. The spread of western juniper in central Oregon. In Proceedings of the Western Juniper Ecology and Management Workshop; General Technical Report PNW-74; USDA Forest Service: Portland, OR, USA, 1978.

5. Eddleman, L.E. General Technical Report INT-US Department of Agriculture: Establishment and Stand Development of Western Juniper in Central Oregon; Forest Service, Intermountain Research Station: Ogden, UT, USA, 1987.

6. Miller, R.F.; Rose, J.A. Historic expansion of Juniperus occidentalis (western juniper) in southeastern Oregon. Great Basin Nat. 1995, 55, 37-45.

7. Soulé, P.T.; Knapp, P.A. Western juniper expansion on adjacent disturbed and near-relict sites. J. Range Manag. 1999, 1, 525-533. [CrossRef]

8. Sankey, T.T.; Germino, M.J. Assessment of juniper encroachment with the use of satellite imagery and geospatial data. Rangel. Ecol. Manag. 2008, 61, 412-418. [CrossRef]

9. Rowland, M.M.; Suring, L.H.; Tausch, R.J.; Geer, S.; Wisdom, M.J. Dynamics of Western Juniper Woodland Expansion into Sagebrush Communities in Central Oregon, Natural Resources and Environmental Issues. In Proceedings of the 15th Wildl and Shrub Symposium, Bozeman, MT, USA, 17-19 June 2008.

10. Campbell, J.L.; Kennedy, R.E.; Cohen, W.B.; Miller, R.F. Assessing the carbon consequences of western juniper (Juniperus occidentalis) encroachment across Oregon, USA. Rangel. Ecol. Manag. 2012, 65, 223-231. [CrossRef]

11. Miller, R.F.; Svejcar, T.J.; Rose, J.A. Impacts of western juniper on plant community composition and structure. Rangel. Ecol. Manag. 2000, 53, 574-585. [CrossRef]

12. Miller, R.F.; Bates, J.D.; Svejcar, A.J.; Pierson, F.B., Jr.; Eddleman, L.E. Biology, Ecology, and Management of Western Juniper (Juniperus Occidentalis); Oregon State University Agricultural Experiment Station: Corvallis, OR, USA, 2005.

13. Petersen, S.L.; Stringham, T.K. Infiltration, runoff, and sediment yield in response to western juniper encroachment in southeast Oregon. Rangel. Ecol. Manag. 2008, 61, 74-81. [CrossRef]

14. Belsky, A.J. Western juniper expansion: Is it a threat to arid northwestern ecosystems? J. Range Manag. 1996, 1, 53-59. [CrossRef]

15. Ahlström, A.; Raupach, M.R.; Schurgers, G.; Smith, B.; Arneth, A.; Jung, M.; Reichstein, M.; Canadell, J.G.; Friedlingstein, P.; Jain, A.K.; et al. The dominant role of semi-arid ecosystems in the trend and variability of the land CO2 sink. Science 2015, 348, 895-899. [CrossRef]

16. Poulter, B.; Frank, D.; Ciais, P.; Myneni, R.B.; Andela, N.; Bi, J.; Broquet, G.; Canadell, J.G.; Chevallier, F.; Liu, Y.Y.; et al. Contribution of semi-arid ecosystems to interannual variability of the global carbon cycle. Nature 2014, 509, 600-603. [CrossRef] [PubMed]

17. Young, J.A.; Evans, R.A. Demography and fire history of a western juniper stand. Rangel. Ecol. Manag. 1981, 34, 501-506. [CrossRef]

18. Soulé, P.T.; Knapp, P.A.; Grissino-Mayer, H.D. Human agency, environmental drivers, and western juniper establishment during the late Holocene. Ecol. Appl. 2004, 14, 96-112. [CrossRef]

19. Miller, R.F.; Rose, J.A. Fire history and western juniper encroachment in sagebrush steppe. J. Range Manag. 1999, 52, 550-559. [CrossRef]

20. Knapp, P.A.; Soulé, P.T. Vegetation change and the role of atmospheric $\mathrm{CO}_{2}$ enrichment on a relict site in central Oregon: 1960-1994. Ann. Assoc. Am. Geogr. 1996, 86, 387-411. [CrossRef] 
21. Knapp, P.A.; Soulé, P.T.; Grissino-Mayer, H.D. Detecting potential regional effects of increased atmospheric $\mathrm{CO}_{2}$ on growth rates of western juniper. Glob. Chang. Biol. 2001, 7, 903-917. [CrossRef]

22. Tognetti, R.; Longobucco, A.; Miglietta, F.; Raschi, A. Transpiration and stomatal behaviour of Quercus ilex plants during the summer in a Mediterranean carbon dioxide spring. Plant Cell Environ. 1998, 21, 613-622. [CrossRef]

23. Wullschleger, S.D.; Tschaplinski, T.J.; Norby, R.J. Plant water relations at elevated $\mathrm{CO}_{2}$-implications for water-limited environments. Plant Cell Environ. 2002, 25, 319-331. [CrossRef]

24. Knapp, P.A.; Soulé, P.T.; Grissino-Mayer, H.D. Post-drought growth responses of western Juniper (Juniperus occidentalis var. occidentalis) in central Oregon. Geophys. Res. Lett. 2001, 28, 2657-2660. [CrossRef]

25. Keenan, T.F.; Hollinger, D.Y.; Bohrer, G.; Dragoni, D.; Munger, J.W.; Schmid, H.P.; Richardson, A.D. Increase in forest water-use efficiency as atmospheric carbon dioxide concentrations rise. Nature 2013, 499, 324-327. [CrossRef]

26. Palmer, W.C. Meteorologic Drought; Office of Climatology U.S. Weather Bureau: Washington, DC, USA, 1965.

27. United States Drought Monitor. Available online: https://droughtmonitor.unl.edu (accessed on 9 March 2019).

28. Rupp, D.E.; Abatzoglou, J.T.; Mote, P.W. Projections of 21st century climate of the Columbia River Basin. Clim. Dyn. 2017, 49, 1783-1799. [CrossRef]

29. Dalton, M.M.; Dello, K.D.; Hawkins, L.; Mote, P.W.; Rupp, D.E. The Third Oregon Climate Assessment Report; Oregon Climate Change Research Institute, College of Earth, Ocean and Atmospheric Sciences, Oregon State University: Corvallis, OR, USA, 2017.

30. Koutavas, A. CO2 fertilization and enhanced drought resistance in Greek firs from Cephalonia Island, Greece. Glob. Chang. Biol. 2013, 19, 529-539. [CrossRef] [PubMed]

31. Allen, C.D.; Breshears, D.D.; McDowell, N.G. On underestimation of global vulnerability to tree mortality and forest die-off from hotter drought in the Anthropocene. Ecosphere 2015, 6, 1-55. [CrossRef]

32. Knapp, P.A.; Soulé, P.T. Use of atmospheric CO2-sensitive trees may influence dendroclimatic reconstructions. Geophys. Res. Lett. 2008, 35. [CrossRef]

33. Pacific Northwest Interagency Natural Areas Network. Available online: http://www.fsl.orst.edu/rna/ (accessed on 9 March 2019).

34. Duchesne, L.; Houle, D.; Ouimet, R.; Caldwell, L.; Gloor, M.; Brienen, R. Large apparent growth increases in boreal forests inferred from tree-rings are an artefact of sampling biases. Sci. Rep. 2019, 9, 6832-6840. [CrossRef] [PubMed]

35. Halvorson, R. Western juniper (Juniperus occidentalis). Kalmiopsis 2013, 20, 25-33.

36. Phillips, N.G.; Buckley, T.N.; Tissue, D.T. Capacity of old trees to respond to environmental change. J. Integr. Plant Biol. 2008, 50, 1355-1364. [CrossRef]

37. Knapp, P.A.; Soulé, P.T. Increasing water-use efficiency and age-specific growth responses of old-growth ponderosa pine trees in the Northern Rockies. Glob. Chang. Biol. 2011, 17, 631-641. [CrossRef]

38. Camarero, J.J.; Gazol, A.; Galván, J.D.; Sangüesa-Barreda, G.; Gutiérrez, E. Disparate effects of global-change drivers on mountain conifer forests: Warming-induced growth enhancement in young trees vs. $\mathrm{CO}_{2}$ fertilization in old trees from wet sites. Glob. Chang. Biol. 2015, 21, 738-749. [CrossRef]

39. Yamaguchi, D.K. A simple method for cross-dating increment cores from living trees. Can. J. For. Res. 1991, 21, 414-416. [CrossRef]

40. Regent Instruments Canada, Inc. WINDENDRO for Tree-Ring Analysis; Regent Instruments Canada, Inc.: Nepean, ON, Canada, 2011.

41. Holmes, R.L. Computer-assisted quality control in tree-ring dating and measurement. Tree-Ring Bull. 1983, $43,69-78$.

42. Cook, E.R.; Holmes, R.L. ARSTAN: Chronology development. In The International Tree-Ring Data Bank Program Library, Version 21 User's Manual; University of Arizona Laboratory of Tree-Ring Research: Tucson, Arizona, 1997; pp. 75-92.

43. Keim, B.D.; Wilson, A.M.; Wake, C.P.; Huntington, T.G. Are there spurious temperature trends in the United States Climate Division database? Geophys. Res. Lett. 2003, 30. [CrossRef]

44. Graumlich, L.J. Subalpine tree growth, climate, and increasing $\mathrm{CO}_{2}$ : An assessment of recent growth trends. Ecology 1991, 72, 1-11. [CrossRef]

45. Wang, G.; Chhin, S.; Bauerle, W.L. Effect of natural atmospheric $\mathrm{CO}_{2}$ fertilization suggested by open-grown white spruce in a dry environment. Glob. Chang. Biol. 2006, 12, 601-610. [CrossRef] 
46. Biondi, F.; Waikul, K. DENDROCLIM2002: A C++ program for statistical calibration of climate signals in tree-ring chronologies. Comput. Geosci. 2004, 30, 303-311. [CrossRef]

47. Fritts, H.C. Tree Rings and Climate; Elsevier: Amsterdam, The Netherlands, 2012.

48. Knutson, K.C.; Pyke, D.A. Western juniper and ponderosa pine ecotonal climate-growth relationships across landscape gradients in southern Oregon. Can. J. For. Res. 2008, 38, 3021-3032. [CrossRef]

49. Peñuelas, J.; Canadell, J.G.; Ogaya, R. Increased water-use efficiency during the 20th century did not translate into enhanced tree growth. Glob. Ecol. Biogeogr. 2011, 20, 597-608. [CrossRef]

50. Eamus, D. The interaction of rising CO2 and temperatures with water use efficiency. Plant Cell Environ. 1991, 14, 843-852.

51. LaMarche, V.C.; Graybill, D.A.; Fritts, H.C.; Rose, M.R. Increasing atmospheric carbon dioxide: Tree ring evidence for growth enhancement in natural vegetation. Science 1984, 225, 1019-1021. [CrossRef]

52. Graybill, D.A.; Idso, S.B. Detecting the aerial fertilization effect of atmospheric CO2 enrichment in tree-ring chronologies. Glob. Biogeochem. Cycles 1993, 7, 81-95. [CrossRef]

53. Bunn, A.G.; Lawrence, R.L.; Bellante, G.J.; Waggoner, L.A.; Graumlich, L.J. Spatial variation in distribution and growth patterns of old growth strip-bark pines. Arct. Antarct. Alp. Res. 2003, 35, 323-330. [CrossRef]

54. Soule', P.T.; Knapp, P.A. Radial growth rate increases in naturally-occurring ponderosa pine trees: A late 20th century CO2 fertilization effect? New Phytol. 2006, 171, 379-390. [CrossRef] [PubMed]

55. Voelker, S.L.; Muzika, R.M.; Guyette, R.P.; Stambaugh, M.C. Historical $\mathrm{CO}_{2}$ growth enhancement declines with age in Quercus and Pinus. Ecol. Monogr. 2006, 76, 549-564. [CrossRef]

56. Battipaglia, G.; Saurer, M.; Cherubini, P.; Calfapietra, C.; McCarthy, H.R.; Norby, R.J.; Francesca Cotrufo, M. Elevated $\mathrm{CO}_{2}$ increases tree-level intrinsic water use efficiency: Insights from carbon and oxygen isotope analyses in tree rings across three forest FACE sites. New Phytol. 2013, 197, 544-554. [CrossRef] [PubMed]

57. Giammarchi, F.; Cherubini, P.; Pretzsch, H.; Tonon, G. The increase of atmospheric $\mathrm{CO}_{2}$ affects growth potential and intrinsic water-use efficiency of Norway spruce forests: Insights from a multi-stable isotope analysis in tree rings of two Alpine chronosequences. Trees 2017, 31, 503-515. [CrossRef]

58. Huang, R.; Zhu, H.; Liu, X.; Liang, E.; Grießinger, J.; Wu, G.; Li, X.; Bräuning, A. Does increasing intrinsic water use efficiency (iWUE) stimulate tree growth at natural alpine timberline on the southeastern Tibetan Plateau? Glob. Planet. Chang. 2017, 148, 217-226. [CrossRef]

59. Gedalof, Z.E.; Berg, A.A. Tree ring evidence for limited direct CO2 fertilization of forests over the 20th century. Glob. Biogeochem. Cycles 2010, 24. [CrossRef]

60. Silva, L.C.; Anand, M. Probing for the influence of atmospheric $\mathrm{CO}_{2}$ and climate change on forest ecosystems across biomes. Glob. Ecol. Biogeogr. 2013, 22, 83-92. [CrossRef]

61. Giguère-Croteau, C.; Boucher, É.; Bergeron, Y.; Girardin, M.P.; Drobyshev, I.; Silva, L.C.; Hélie, J.F.; Garneau, M. North America's oldest boreal trees are more efficient water users due to increased $\left[\mathrm{CO}_{2}\right]$, but do not grow faster. Proc. Natl. Acad. Sci. USA 2019, 116, 2749-2754. [CrossRef]

62. Linares, J.C.; Camarero, J.J. From pattern to process: Linking intrinsic water-use efficiency to drought-induced forest decline. Glob. Chang. Biol. 2012, 18, 1000-1015. [CrossRef]

63. Way, D.A. Will rising $\mathrm{CO}_{2}$ and temperatures exacerbate the vulnerability of trees to drought? Tree Physiol. 2013, 33, 775-778. [CrossRef] [PubMed]

(C) 2019 by the authors. Licensee MDPI, Basel, Switzerland. This article is an open access article distributed under the terms and conditions of the Creative Commons Attribution (CC BY) license (http://creativecommons.org/licenses/by/4.0/). 